ISSN 0103-5150

Fisioter. Mov., Curitiba, v. 30, n. 3, p. 527-536, Jul./Sep. 2017

Licenciado sob uma Licença Creative Commons

DOI: http://dx.doi.org/10.1590/1980-5918.030.003.A011

\title{
Assistance provided by physical therapists from primary health care to patients after stroke
}

\author{
Assistência do fisioterapeuta da atenção primária \\ a indivíduos pós-acidente vascular cerebral
}

\author{
Christina Danielli Coelho de Morais Faria, Danielle Campos Araújo, \\ Bárbara Paula de Barros Carvalho-Pinto*
}

Universidade Federal de Minas Gerais (UFMG), Belo Horizonte, MG, Brazil

\begin{abstract}
Introduction: Motor impairments, which are prevalent in stroke subjects, require physical therapy (PT) rehabilitation. In primary care in the Brazilian Public Health System, PT are part of the Núcleo de Apoio à Saúde da Família (NASF). Objective: To describe the PT assistance provided to stroke patients in a primary healthcare center. Methods: The records of all stroke patients ( $n=44 ; 69.23 \pm 13.12$ years) identified by the health professionals were analyzed. Using keyword recognition, frequency analysis of the services offered by the PT was performed. Subjects were classified according to the Modified Rankin Scale. Results: In the 44 records, $45.5 \%$ had a description of the assistance provided by any professional of the NASF and $36.4 \%$ of the PT care. PT care was provided at the subject's home (94.2\%) and the healthcare center (5.8\%). The PT practices were identified as: orientation (93.8\%), evaluation (87.5\%), exercises (50\%), follow-up (37.5\%), referral to another service or to undergrad PT students (18.8\%), and referral to other NASF professionals $(12.5 \%)$. Most of the subjects were classified as having mild/moderate disability. Conclusion: The minority of records had registration of attendance by the NASF PT. The majority of the sessions occurred at the subject's home, which reveals a practice focused on individual care. The orientation was common, which illustrates that in primary care there is a focus on empowerment for health self-improvement. Follow-up was not common, despite clinical guidelines state that stroke subjects should be monitored at least once a year by the rehabilitation team.
\end{abstract}

Keywords: Primary Healthcare. Physical Therapy. Stroke.

CDCMF: PhD, e-mail: cdcmf@ufmg.br

DCA: BS, e-mail: danni.campos@hotmail.com

BPBCP: MS, e-mail: bita_fisio@hotmail.com

Fisioter Mov. 2017 Jul/Sep;30(3):527-536 
Resumo

Introdução: Deficiências motoras são prevalentes após o Acidente Vascular Cerebral (AVC), necessitando de atendimento fisioterápico (AF). Na atenção básica (AB) do Sistema Único de Saúde, os fisioterapeutas fazem parte do Núcleo de Apoio à Saúde da Família (NASF). Objetivo: Descrever o perfil da RF do NASF aos indivíduos pós-AVC usuários da AB. Métodos: Os prontuários de todos indivíduos pós-AVC $(n=44)$ foram analisados. Com o reconhecimento de palavras-chave, realizou-se análise de frequência das condutas do AF. Em seguida, os indivíduos foram avaliados quanto à auto-percepção de saúde e incapacidade (Escala Modificada de Rankin).

Resultados: A maioria avaliou sua saúde como razoável ou ruim (61\%) e 31,8\% apresentaram incapacidade severa. Apesar disso, apenas 45,5\% dos prontuários apresentava registro de assistência do NASF, sendo o AF o mais frequente: 36,4\% receberam AF, com um total de 35 atendimentos. Desses, 94,2\% foram em domicílio, contemplando as seguintes condutas: orientação (93,8\% dos casos), avaliação (87,5\%), tratamento (50\%), acompanhamento (37,5\%), encaminhamento a outro serviço ou para acadêmicos da fisioterapia $(18,8 \%) e$ encaminhamento a outro profissional do NASF (12,5\%). Conclusão: Apesar de ser o profissional do NASF com atendimento mais frequente, a minoria dos prontuários apresentava registro de AF. Os atendimentos ocorreram, principalmente, em domicílio, revelando que a prática profissional pauta-se em atendimentos individualizados. A grande quantidade de orientação ilustra que a fisioterapia na AB contempla o empoderamento como cuidado à saúde. O acompanhamento foi uma prática pouco frequente, apesar de estabelecido em guias clínicos que indivíduos pós-AVC devem ser acompanhados pelo menos anualmente pela equipe de reabilitação.

Palavras-chave: Atenção Primária à Saúde. Fisioterapia. Acidente Vascular Cerebral.

\section{Introduction}

The prevalence of stroke is very high, particularly in developing countries such as Brazil (1) in which the incidence of stroke keeps increasing in the growing aging population. This situation may possibly lead to a more significant increase in the prevalence of stroke survivors $(1-5)$. The majority of stroke survivors exhibit some degree of disability $(6,7)$ such as motor impairments $(8-10)$. Therefore, it is essential that these patients be cared for by rehabilitation teams, especially physical therapists (11 - 13).

Rehabilitation of stroke patients should be early and comprehensive $(14,15)$. According to clinical guides $(11,16)$, post-stroke rehabilitation should begin in the acute stage, during hospitalization, as soon as any threats to life have been addressed. After the acute stage, it is known that the best clinical results are obtained when patients referred to rehabilitation are assessed and then treated by a coordinated and interdisciplinary team. It is recommended that stroke survivors be treated by interdisciplinary teams beyond the hospital setting and ideally at home. To make this situation a reality, community services with available resources for post-stroke rehabilitation need to be offered (16).
In 2012, the Ministry of Health approved Ordinance MS/GM number 665 pertaining to the Care Pathways for Stroke ("Linha de Cuidados em $A V C^{\prime \prime}$ ) (17). This ordinance made outpatient followup care after hospital discharge possible, and it included aspects of rehabilitation, specialized home care and social reintegration of post-stroke patients. These care pathways note the necessity of delivering integrated and continuous care and the importance of making this care available at different health care levels because such levels are essential for adequate flow of care (17).

Basic Care (BC), which is the main point of entry to the healthcare system and the point of communication with the entire Healthcare Network (18), is characterized by a set of healthcare actions that encompass health promotion, disease prevention, diagnosis, treatment, rehabilitation, damage reduction and health maintenance, aiming at delivering holistic healthcare to the population in its coverage area (17). In the case of the Care Pathways for Stroke, BC is not limited to acute events (17). Stroke patients should receive comprehensive care, which is not restricted to the prescription of medicine, but rather involves the provision of care by an interdisciplinary team, the promotion of self-care and shared care, risk stratification and close followup of "higher-risk" patients. When stroke patients are 
discharged from hospital, the Family Health (FH) team of the Basic Health Unit (BHU) should be notified in order to perform their follow-up (17).

Aiming at supporting the insertion in the services network of the FH team and ensuring the provision of continuous and integral healthcare to patients, the Ministry of Healh created the Family Health-Care Support Centre (Núcleo de Apoio à Saúde da Família (NASF)), through Ordinance GM number 154. This concretized the insertion of physical therapists in $\mathrm{BC}$ as members of the NASF team (19). Primary care users identify physical therapists as an important member of the rehabilitation team, as they facilitate their access to physical therapy services and the expansion of holistic healthcare (20).

The general goal of the physical therapy treatment of stroke patients is to re-establish functions and/or minimize existing disabilities, enabling patients to return to their previous activity status and participate again in social life (12). Moreover, as healthcare professionals, physical therapists should focus on the prevention of disabilities and diseases, as well as on the promotion of functionality and health $(6$, 7, $11-13,16,19,20)$. Specifically at Basic Care level, physical therapists should work according to their guidelines: interdisciplinary and intersectorial work, continuing health education of professionals and the population, development of the idea of territory, holism, social participation, popular education, health promotion and humanization (21). Direct interventions of NASF physical therapists for users and families may occur, but they should always take place in the form of referrals and after discussion by the professionals responsible for the case. The provision of direct and individualized care by a physical therapist will only occur when absolutely necessary. The different intervention types in the territory should also be kept in mind, such as the development of health projects, provision of support to groups, educational work and social inclusion. All tasks should be performed in coordination with the other teams (21).

Aiming at investigating how continuing healthcare is delivered to stroke patients, taking into account what is established in the Care Pathways for Stroke and the NASF guidelines, as well as physical therapists responsibilities as health professionals and members of the rehabilitation team, this study aimed to describe the profile of care provided by NASF physical therapists to stroke primary care users in the Brazilian Unified Health System (SUS).

\section{Methods}

It was conducted a cross-sectional descriptive study with stroke patients from Primary Healthcare (PHC) within the SUS (area covered by the BHU of the northern sanitary district of Belo Horizonte city). This study was approved by the Research Ethics Committee of the Federal University of Minas Gerais/ Brazil (UFMG), and the Municipal Health Secretariat of Belo Horizonte city (CAAE: 14038313.4.0000.5149. Data collection took place between May 2013 and May 2014, during two days. On the first day, data were collected from patients' medical records at the Basic Health Unit; while on the second day data were collected during a home visit.

\section{Sample}

All stroke patients who fulfilled the inclusion criteria and were identified by the FH or NASF team as BHU users participated in the study. Inclusion criteria were patients aged 20 or over with clinical diagnosis of primary or recurrent stroke over six months and properly recorded in the medical records, who lived in the area covered by the BHU, were UHS users registered at the reference $\mathrm{BHU}$ and identified by a BHU worker. All participants who chose to participate signed an informed consent document.

\section{Data collection procedures}

Information about the study was first presented to the manager and team members of the BHU. In order to identify stroke patients, a research team member participated at least once a month in the meetings of the BHU team. Once the patients had been identified as stroke patients, their BHU medical records would be analyzed and then they would be invited to participate in the study. Those who, together with their caregivers, chose to participate in the study were assessed for motor or sensitive aphasia, and screened on cognitive function using the Mini-Mental State Examination (MMSE) and cut-off based on education level $(22,23$, 24). Patients without any kind of aphasia and with adequate cognitive function $(22,23,24)$ were interviewed to confirm the data contained in their medical records and self-assessed their health (health self-perception) (25). In the case of the other patients, their caregiver 
checked the data taken from their medical records and health self-evaluation was performed.

All patients were classified by impairment level using the Modified Rankin Scale (MRS) (26). The MRS is one of the most widely used measures of functionality/impairment in stroke patients. Its translated version nto Brazilian Portuguese exhibits good validity and reliability (27). All data were collected by a single researcher/physical therapist and assisted by another researcher. Both researchers had been previously trained with regard to the tasks.

With regard to the data contained in the medical records, it was first collected those data associated with the characterization of the sample, namely: age, stroke-related clinical data such as number of episodes, type, side affected by it and evolution time. Next, it was collected data for the characterization of the profile of care provided by NASF physical therapists: place where patients were treated and types of intervention performed (guidance, which consisted, for instance, of explanations on home exercises, proper bed positioning and use of assistive gait devices); physical therapy evaluation - which guides clinical decision making; physical therapy treatment - defined as interventions directly performed by the physical therapist, such as supervised exercises during treatment; follow-up characterized as two or more care sessions; referral to another healthcare service; referral to undergraduate physical therapy students of UFMG; referral to another NASF professional. A previously elaborated evaluation form was used to collect the data. I the specific case of the variable used to determine the types of intervention performed by NASF physical therapists, data were collected as follows: professionals' records were read and analyzed so that keywords associated with each one of the categories previously described could be identified. It was calculated the frequency of each category.

\section{Data analysis procedures}

Kolmogorov-Smirnov test was used to verify the normality of quantitative variables. All of them were normally distributed. Thus, it was used median and standard deviation to the descriptive statistical analysis. For descriptive analysis of categorical variables, frequency analysis was performed. All statistical analyses were conducted using the statistical software SPSS ${ }^{\circledR}$ for Windows, version 17.0, (SPSS Inc., Chicago, Illinois, USA).

\section{Results}

The first analysis identified 66 potential study participants. After analyzing their medical records, it was found that $13.6 \%(n=9)$ had no clinical diagnosis of stroke (although they had been identified by a Family Health team member as a stroke patient); $9 \%(n=6)$ were not registered at the BHU (because they only visited the BHU to collect their prescribed medicines and had, therefore, no medical records there); $4.5 \%$ $(n=3)$ no longer lived in the area covered by the unit (one patient had moved to the countryside and two subjects had been institutionalized); and 3\% $(\mathrm{n}=2)$ had passed away. Two patients chose not to participate in the study. Thus, in total 44 subjects were included in the study.

As shown in Table 1, most participants were female (54.5\%), with a mean age of $69.2 \pm 13.1$ years and mean stroke evolution time of $67 \pm 66.5$ months. With regard to health self-perception, of 44 patients, two could not speak because they were tracheostomized, five had motor and/or sensitive aphasia, and one had a diagnosis of severe dementia. Thus, $18.2 \%(n=8)$ of participants were not able to selfassess their health. Of 36 patients who were able to self-assess their health, $47 \%(n=17)$ considered it "reasonable", whereas 14\% ( $\mathrm{n}=5)$ rated it as "bad". All 44 participants were assessed with regard to their impairment level. Most patients 31,8\%, $(n=14)$ had moderate impairment while $20.5 \%(n=9)$ had mild impairment (Table 1).

Table 1 - Clinical and demographic variables

\begin{tabular}{lc}
\hline Variables & $\mathbf{n}=44$ \\
\hline Gender, \% (n) & $54.5(24)$ \\
$\quad$ Female & $45.5(20)$ \\
$\quad$ Men & $69.23(13.12)$ \\
Age (years), mean (SD) & \\
Episodes of stroke, \% (n) & $68.2(30)$ \\
$\quad$ One episode & $31.8(14)$ \\
Two or more episodes & \\
Stroke type, \% (n) & $68.2(30)$ \\
Ischemic & $18.2(8)$ \\
Hemorrhagic & $13.6(6)$ \\
No information on medical & \\
record/Not able to inform & \\
Involvement aside, \% (n) & \\
Right & $52(23)$ \\
Left & $45.5(20)$ \\
Both sides & $2.3(1)$
\end{tabular}


Table 1 - Clinical and demographic variables

\begin{tabular}{lc}
\hline Variables & $\mathbf{n}=44$ \\
\hline Self-perception of Health, \% (n) & \\
Very bad & $11(4)$ \\
Bad & $14(5)$ \\
Reasonable & $47(17)$ \\
Good & $9(3)$ \\
Very good & $9(3)$ \\
Great & $11(4)$ \\
Impairment level*, \% (n) & \\
Without impairment & $15.9(7)$ \\
Mild impairment & $20.5(9)$ \\
Moderate impairment & $31.8(14)$ \\
Marked impairment & $15.9(7)$ \\
Severe impairment & $15.9(7)$ \\
\hline
\end{tabular}

Note: * Modified Rankin Scale.

It was found that most medical records $(54,5 \%$, $\mathrm{n}=24$ ) had no records of treatment/follow-up by a NASF professional after discharge. Of the $45.5 \%$ $(n=20)$ who had some kind of record, $65 \%(n=13)$ were first cared at the NASF by a physical therapist (Figure 1). Considering all records of care provided by NASF team, it was found that patients were cared for by five of the eight health professionals who are part of the interdisciplinary team, and that $80 \%$ of these treatments were conducted by physical therapists $\mathrm{n}=16$ ) by a (Figure 2). Physical therapists were the only members of the NASF team who delivered care to more than half of the patients.

In the 20 medical records analyzed it was found that physical therapists had provided a total of 35 care sessions. The characterization of these sessions revealed that most ( $94.2 \%, \mathrm{n}=33$ ) had been homecare sessions and that the most common services provided by NASF physical therapists were orientation (in $93.8 \%$ of the cases) and physical therapy evaluation ( $87.5 \%$ of the cases), whereas the least common service was referral to another NASF professional (12.5\%) (Figure 3).

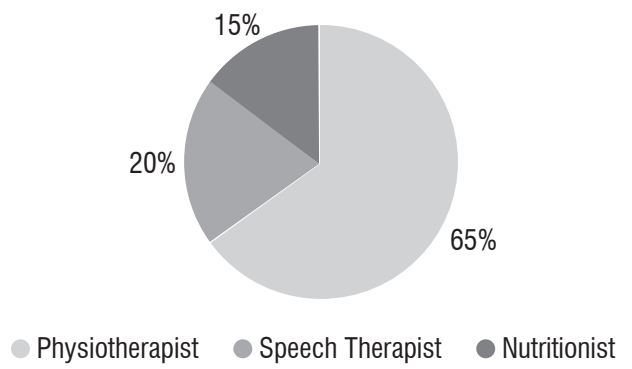

Figure $\mathbf{1}$ - Percentage of first assistance to stroke patients categorized by NASF professional according to the medical records at primary healthcare center.

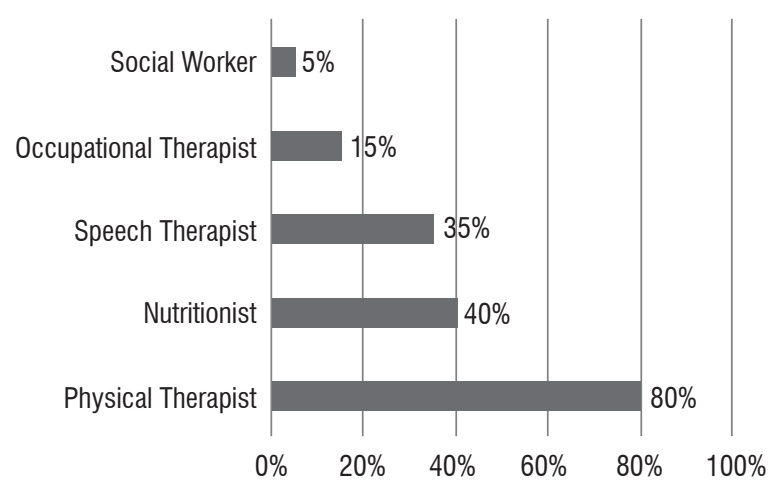

Figure 2 - Percentage of home care provided by each professional of Family Health-Care Support Centre to stroke patients according to the medical records at primary healthcare center.

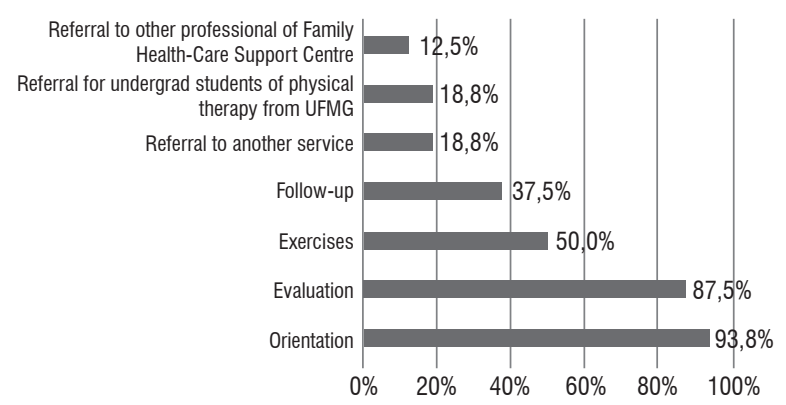

Note: UFMG - Federal University of Minas Gerais/Brazil.

Figure 3 - Percentage of care sessions carried out by the physical therapist of Family Health-Care Support Centre to stroke patients according to the medical records at primary healthcare center.

\section{Discussion}

This study describes the profile of care provided by NASF physical therapists to primary care users after stroke in the SUS, who, in their majority, selfperceived their health as "fair" to "poor" and had mild to moderate impairment level. Less than half of the medical records of stroke patients had records of care provision by NASF professionals: only five of the eight professionals who constituted the NASF healthcare team register information on the medical records. Physical therapists were the NASF team members who first saw and delivered care to most of the patients, but this information was documented in only one third of the medical records of stroke patients. Most of the physical therapy sessions took place at the patients' home, and the most common service provided by physical therapists was orientation, 
while the least common service delivered by them was referral to another NASF professional.

The first important issue to be discussed is the high percentage of patients who had first been identified by NASF professionals as stroke patients, but who in reality had no such diagnosis. This leads us to question the perspicuity and even the level of understanding of stroke by these professionals and the BHU users. This result could suggest that the opposite has also occurred, i.e., that stroke BHU users may not have been identified as such by BHU health professionals. Lack of stroke-related knowledge among FH team members may contribute to the provision of inadequate care. Neves et al. (28) conducted a field study with healthcare about difficulties, doubts, and the importance of receiving guidance on how to provide care to stroke patients. They found that most professionals (85\%) followed no guidelines, guides or guideline manuals to provide care to stroke patients. The non-use of such documents was attributed to the unawareness of their existence. Moreover, it was found that, as professionals get to know more about other areas of care to stroke patients, they get to apply their general condition-related knowledge, which leads to an improvement of their professional skills (28). Therefore, stroke-related training and education for health professionals should be planned and implemented within the SUS.

Patient flow issues at the study site, including patient referral to a NASF physical therapist who used to assist the FH team, may justify the high percentage of patients who had first been identified by NASF professionals as stroke patients, but who in reality had no such diagnosis, as well as the occurrence of the opposite: the non-identification of true stroke patients. According to the Care Pathways for Stroke (17), "after a patient discharged from hospital, the BHU should be notified in order to monitor and follow-up the patient's progress". Moreover, it is also recommended that "all patient care is coordinated by the basic health team" and "if the BHU team is supported by the NASF, users' cases should be discussed between both teams to assess the need for joint care or any specific actions from the different professional groups" (17). At the study site, notification of hospital discharge did not occur for all cases. The FH and NASF teams were notified of some patients' health conditions by community health workers (CHW) or as they or their family members/caregivers spontaneously visited one of the healthcare services to receive care. Nevertheless, all notified cases and those of which the FH team was aware through information from CHW or spontaneous demand were discussed with the NASF team to assess patients' care needs, as recommended in the Care Pathways for Stroke (17). This was discussed once a month at the joint meetings between FH or NASF team members. The findings highlight the importance of hospital discharge notification for the adequate monitoring and followup of stroke patients, as recommended in the Care Pathways for Stroke (17).

The clinical profile of the study sample is similar to that of previous studies conducted with stroke UHS users $(29,30)$. Ribeiro et al. (29) have also reported a homogeneous distribution of males (47.9\%) and females $(52.1 \%)$, mostly aged 60 years or older (73.6\%), with a mean age of 63.3 years. In addition, their findings were similar to this study regarding stroke side (44.3\% right and $41.4 \%$ left). Costa et al. (30) assessed patients' clinical features and, like in this study, found that ischemic stroke was the most common etiology. The fact that patients $13.6 \%$ in this study) had no information regarding stroke type on their medical records and were not able to provide this information during home visits was also reported by Paixão (31). These results evidence major failures in registering information relating to patients in the information system of the unit, and could indicate a gap in information quality and communication between UHS referral and counter-referral sites.

Most participants in this study self-perceived their health as "fair" to "poor". Arruda et al. (32) underline that health self-perception is a health needs marker that indicates how people's lives are affected by their health status. Additionally, it has already been shown that health self-perception is significantly associated with the use of health services (33). As mentioned above, most study participants had mild to moderate impairment. This ratifies the profile presented by Schepers et al. (34), who described stroke patients as having chronic, complex and heterogeneous impairments that may result in functionality-related problems. In another study (35) that aimed to describe rehabilitation activities in stroke patients from Artemisa, Cuba, $43 \%$ of study participants had moderate impairments according to the MRS (26).

Although most patients in this study self-assessed their health as "fair" to "poor" and over $30 \%$ of the sample was composed of subjects with severe to moderately severe impairment, it was found that more 
than half (54.5\%) of patients' medical records had no records of care provision by a NASF professional. And that despite the fact that the NASF is an important innitiative in response to the problem of continuity in rehabilitation care (36). Since the Care Pathways for Stroke (17) recommend that "the BHU is notified of a patient's discharge from hospital, in order to be able to provide monitoring and follow-up" and if the team is supported by a NASF, "patients cases should be discussed with NASF professionals to assess the need for joint care or any specific actions from the different professional groups", it was expected to find at least one properly recorded evaluation for each patient identified by the healthcare team as stroke BHU patients, but that was not the case here.

Given that physical therapy is a highly requested rehabilitation area in the functional recovery process of stroke patients $(6,11,12,13)$, it is of paramount importance that physical therapists know the profile of patients in their coverage area, in order to determine what would be the best care to these patients. Yet in this study, only 16 of 44 medical records had records of physical therapy care, and this although a great number of patients had been classified as having moderate impairment. It was raised the hypothesis that functionality and impairment indicators are not necessarily guiding these professionals in their systematization/planning of care provision. If that is the case, it could be that other indicators are being used as a reference to plan the provision of care or else it could be that, in reality, there is no reference indicator available to perform such planning. Future studies should address this issue.

With regard to the profile of the care provided in the study site, some findings indicate quality of care deficiencies, while others show the effectiveness of basic health services. The fact that most of the care was provided individually makes us question whether they were really necessary, given that the recommendation is that home care is only provided in extreme cases (21). As established in the $\mathrm{BC}$ guidelines (21), NASF physical therapists can deliver other types of care, not only individual care. It is up to these professionals to develop health and support programs for patients with similar healthcare needs. Our results show that some patients have benefited from this kind of intervention.

The fact that the most common service provided by physical therapists was orientation reveals that these professionals have been making use of patient and family empowerment strategies at $\mathrm{BC}$ to broaden health healthcare services. Patient empowerment is used in health education activities to promote health (37). The BC physical therapist is one of the professionals who are supposed to conduct these activities, promoting actions that lead to health outcomes and individual behavioral changes (38), shaping opportunities for patients to become co-managers of their health.

It is important to stress that, according to the medical records, physical therapy evaluation was not performed for all patients. This evaluation, however, is one of the most important responsibilities of physical therapists (39), because the results of this evaluation are used as a basis for clinical decision-making, with the ultimate goal of providing the best possible care to patients. It is through the evaluation that physical therapists become able to design and prescribe interventionist goals (39). Thus, the question that arises is: how were they able to make clinical decisions without performing a physical therapy evaluation first? Or did they perform the evaluation but did not register it on the medical records, rather only the decision made? If that is the case, it is important to emphasize the importance of proper recording relevant data on patients' medical records. They should not only be filled out and organized so as to allow others to easily find, read and identify their authors, but also comprehensive, objective and concise, as they are going to be used by professionals directly related to the provision and manage of care, researchers, professors, health students and patients as a source of data that enables them to assess the quality of healthcare delivery $(40,41)$. Resolution number 414/2012 of the Federal Council of Physical Therapy and Occupational Therapy (COFITO) states that "the recording of the care provided by physical therapists to patients on their medical records is mandatory". The resolution also specifies which information should be recorded in detail, including those related to the physical therapy evaluation: II-Clinical history: main complaint, life habits, current and previous history of the disease, personal and family history, treatments performed; III - Clinical/physical examination: functional physical health status according to physiotherapeutic semiology; IV - Complementary examinations: description of all complementary examinations previously performed and those requested by the physical therapist himself; $\mathrm{V}$ - Physiotherapeutic diagnosis and prognosis: description of the physiotherapeutic diagnosis considering the patient's physical 
health status, indicating the probable physiotherapeutic prognosis and including an estimate of how the case will evolve; VI - Therapeutic plan: description of the proposed physical therapy procedures, resources, methods and techniques to be used, as well as the therapeutic goal(s) to be achieved and the probable care quantity. Thus, physical therapists are obliged to record the physical therapy evaluation on the patient's medical records (42).

The results of the present study show that only fifty percent of the cases received physical therapy care, with a total of 35 interventions being recorded on the medical records. This leads us to infer that the care provided by physical therapists did not achieve satisfactory results, as it did not follow the premise of continuity. Moreover, follow-up was not a very common practice, although current clinical guides recommend that stroke patients are followed-up at least annually by the rehabilitation team $(14,15)$.

Referrals to other healthcare services, to undergraduate physical therapy students of UFMG or to other NASF professionals were, in isolation, uncommon practices, but together made up a significant proportion of cases. These referrals can be seen as a transfer of healthcare responsibility, which has to be done in a judicious way and, according to the Ministry of Health (43), should take into account "the healthcare need and clinical indication, as well as the seriousness of the problem". Given the above, it is important to highlight: how important it is for physical therapists to know the network flow within the SUS in order to be able to properly refer patients to other healthcare services; the need to strengthen bonds between educational institutions that offer internship programs in $\mathrm{BC}$ and $\mathrm{BC}$ professionals, properly training the latter to work together with undergraduate students; the improvement of the work performed by the multidisciplinary team, ensuring that the various professionals who work at the NASF are able to recognize patients' needs and solve problems, according to their specific knowledge.

\section{Conclusion}

It was found a supply and demand gap in healthcare provision by NASF professionals to stroke patients. Physical therapists were the NASF team members who first saw and delivered care to most of the patients. Most of the physical therapy sessions took place at the patients' home, and the most common service provided by physical therapists was orientation. Nevertheless, less than half of the BHU stroke patients were provided physical therapy care.

We hope that our findings enable the discussion, planning and implementation of healthcare strategies by NASF professionals, especially physical therapists, and that these strategies include follow-up and care specifically targeted at stroke patients, and are based on clearly established criteria and meet the recommendations made in clinical guides and the care pathways suggested by the Ministry of Health.

Some limitations of this study must be considered: the fact that participants were only identified based on the reports of FH and NASF professionals; the lack of proper recording on medical records, although this is a mandatory duty, and the fact that these documents were the only ones used for data collection; the fact that the profile of the care provided is closely related to the training, education, principles and attitudes of professionals, which were not analyzed in this study.

\section{Acknowledgements}

We thank the Ministry of Healh/Brazil, the Minas Gerais Research Foundation (Fundação de Amparo à Pesquisa do Estado de Minas Gerais - FAPEMIG), the Brazilian Federal Agency for Support and Evaluation of Graduate Education (Coordenação de Aperfeiçoamento de Pessoal de Nível Superior-CAPES), the National Council for Scientific and Technological Development (Conselho Nacional de Desenvolvimento Científico e Tecnológico - CNPq) and the Dean of Research of the Federal University of Minas Gerais (Pró-reitoria de Pesquisa da Universidade Federal de Minas Gerais /Universidade Federal de Minas Gerais PRPq / UFMG) for the financial support.

\section{References}

1. Mozaffarian D, Benjamin EJ, Go A, Arnett DK, Blaha MJ, Cushman M, et al. Heart disease and stroke statistics-2015 update: a report from the American Heart Association. Circulation. 2015;131(4):e29-322. 
2. Chatterji S, Byles J, Cutler D, Seeman T, Verdes E. Health, functioning, and disability in older adultspresent status and future implications. Lancet. 2015;385(9967):563-75.

3. Prince MJ, Wu F, Guo Y, Robledo LMG, O'Donnell $\mathrm{M}$, Sullivan $\mathrm{R}$, et al. The burden of disease in older people and implications for health policy and practice. Lancet. 2015;385(9967):549-562.

4. Sistema de Informações Hospitalares do SUS. IBGE: Bases Demográficas. [cited 2014 Oct 15]. Available from: http://tinyurl.com/gsw8jsk.

5. Lotufo PA. Stroke in Brazil: a neglected disease. Sao Paulo Med J. 2005;123(1):3-4.

6. Young J, Forster A. Rehabilitation after stroke. BMJ. 2007;334(7584):86-90.

7. Carvalho-Pinto BPB, Faria CDCM. Health, function and disability in stroke patients in the community. Braz J Phys Ther. 2016;20(4):355-66.

8. Arene N, Hidler J. Understanding motor impairment in the paretic lower limb after a stroke: a review of the literature. Top Stroke Rehabil. 2009;16(5):346-56.

9. Faria CDCM, Saliba VA, Teixeira-Salmela LF. Musculoskeletal biomechanics in sit-to-stand and stand-to-sit with stroke subjects: a systematic review. Fisioter Mov. 2010;23(1):35-52.

10. Martins JC, Aguiar LT, Lara EM, Teixeira-Salmela LF, Faria CDCM. Assessment of grip strength with the modified sphygmomanometer test: association between upper limb global strength and motor function. Braz J Phys Ther. 2015;19(6)498-506.

11. Brasil. Ministério da Saúde. Secretaria de Atenção à Saúde. Departamento de Ações Programáticas Estratégicas. Diretrizes de atenção à reabilitação da pessoa com acidente vascular cerebral. Brasília: Ministério da Saúde; 2013.

12. De Wit L, Putman K, Lincoln N, Baert I, Berman P, Beyens H, et al. Stroke rehabilitation in Europe: what do physiotherapists and occupational therapists actually do? Stroke. 2006;37(6):1483-9.

13. Teixeira-Salmela LF, Faria CDCM, Polese JC, Scianni, A. Evidências científicas de intervenções fisioterapêuticas em pacientes pós-acidente vascular encefálico. In: Profisio Neurofuncional. 1st ed. Porto Alegre: Artmed; 2014. p. 9 - 48.
14. National Collaborating Centre for Chronic Conditions (UK). National Clinical Guideline for Diagnosis and Initial Management of Acute Stroke and Transient Ischaemic Attack (TIA). Royal College of Physicians of London; 2008.

15. National Stroke Foundation. Clinical Guidelines for Stroke Management. National Stroke Foundation, Melbourne; 2010.

16. Duncan PW, Zorowitz R, Bates B, Choi JY, Glasberg JJ, Graham GD, et al. Management of adult stroke rehabilitation care: a clinical practice guideline. Stroke. 2005;36(9):e100-43.

17. Brasil. Ministério da Saúde. Linha de cuidados em acidente vascular cerebral (AVC) na rede de atenção às urgências e emergências. Brasília: Ministério da Saúde; 2012.

18. Portal da Saúde. Política nacional de atenção básica. [cited 2015 Feb 10]. Available from: http://tinyurl. com/gluehps.

19. Formiga NFB, Ribeiro KSQS. Inserção do fisioterapeuta na $\mathrm{AB}$ : uma analogia entre experiências acadêmicas e a proposta dos Núcleos de Apoio à Saúde da Família (NASF). Re Bras ci Saúde. 2012;16(2):113-22.

20. Ferretti F, Nierotka RP, Braghini CC, Arruda CRP, Ferraz L, Fanticelli ML. Physical therapist insertion in the Family Health Strategy team: the users' view. Fisioter Mov. 2015;28(3):485-93.

21. Brasil. Ministério da Saúde. Secretaria de Atenção à Saúde. Departamento de Atenção Básica. Cadernos de atenção básica: Diretrizes do Núcleo de Apoio à Saúde da Família. Brasília: Ministério da Saúde; 2009.

22. Bertolluci PHF, Brucki SMD, Campacci SR, Juliano Y. O mini-exame do estado mental em uma população geral. Arq Neuro-Psiquiatr.1995;52(1):1-7.

23. Cumming TB, Churilov L, Linden T, Bernhardt J. Montreal Cognitive Assessment and Mini-Mental State Examination are both valid cognitive tools in stroke. Acta Neurol Scand. 2013;128(2):122-9.

24. Brucki SM, Nitrini R, Caramelli P, Bertolucci PH, Okamoto IH. Suggestions for utilization of the minimental state examination in Brazil. Arq NeuroPsiquiatr. 2003;61(3):777-81.

25. Ferraro KF, Su YP. Physician-evaluated and selfreported morbidity for predicting disability. Am J Public Health. 2000;90(1):103-8. 
26. Wilson JT, Hareendran A, Grant M, Baird T, Schulz UG, Muir KW, et al. Improving the assessment of outcomes in stroke use of a structured interview to assign grades on the Modified Rankin Scale. Stroke. 2002;33(9):2243-6.

27. Caneda MAG, Fernandes JG, Almeida AG, Mugnol FE. Confiabilidade de escalas de comprometimento neurológico em pacientes com acidente vascular cerebral. Arq Neuro-Psiquiatr. 2006;64(3a):690-7.

28. Neves PP, Fontes SV, Fukujima MM, Matas SLA, Prado GF. Profissionais da saúde, que assistem pacientes com acidente vascular cerebral, necessitam de informação especializada. Rev Neurocienc. 2004;12(4):173-81.

29. Ribeiro KSQS, Neves RF, Brito GEG, Morais JD, Lucena EMF, Medeiros JM, et al. Perfil de usuário acometidos por acidente vascular cerebral adscritos à estratégia saúde da família em uma capital do nordeste do Brasil. R bras ci Saúde. 2013;16(Suppl 2):35-44.

30. Costa FA, Silva DLA, Rocha VMD. Severidade clínica e funcionalidade de pacientes hemiplégicos pós-AVC agudo atendidos nos serviços públicos de fisioterapia de Natal (RN). Ciênc Saúde Colet. 2011;16(Suppl 1):1341-8.

31. Paixão LM. Perfil da funcionalidade em indivíduos acometidos por acidente vascular encefálico na cidade de Campina Grande-PB [Monograph]. Campina Grande: Universidade Estadual da Paraíba; 2012.

32. Arruda GO, Santos AL, Teston EF, Cecilio HPM, Radovanovic CAT, Marcon SS. Associação entre autopercepção de saúde e características sociodemográficas com doenças cardiovasculares em indivíduos adultos. Rev Esc Enferm USP. 2015;49(1):61-8.

33. Brasil. Ministério da Saúde. Secretaria de Vigilância em Saúde. Departamento de Vigilância de Doenças e Agravos não Transmissíveis e Promoção da Saúde. Vigitel Brasil 2012: Vigilância de Fatores de Risco e Proteção para Doenças Crônicas por Inquérito Telefônico. Brasília: Ministério da Saúde; 2013.

34. Schepers VPM, Ketelaar M, Van de Port IGL, VisserMeily JMA, Lindeman E. Comparing contents of functional outcome measures in stroke rehabilitation using the International Classification of Functioning. Disabil Rehabil. 2007;29(3):221-30.
35. Morera EA, Machado JM, Puldón LP. Atención rehabilitadora de la enfermedad cerebrovascular en el municipio Artemisa. Rev Cubana Med Gen Integr. $2010 ; 26(2)$.

36. Reis DC, Flish TMP, Vieira MHF, Santos-Junior WS. Perfil de atendimento de um Núcleo de Apoio à Saúde da Família na área de reabilitação, Município de Belo Horizonte, Estado de Minas Gerais, Brasil, 2009. Epidemiol Serv Saúde. 2012;21(4):663-74.

37. World Health Organization. Health promotion evaluation: recommendations to policy-makers. Report of the WHO European Working Group on Health Promotion Evaluation. [cited 2015 Jan 23]. Available from: http://tinyurl.com/j7mrtfx.

38. Candeias NMF. Conceitos de educação e de promoção em saúde: mudanças individuais e mudanças organizacionais. Rev Saúde Pública. 1997;31(2):209-13.

39. Llano JS, Miranda HCFS, Felippe LA, Andrade LP, Silva CD, Christofoletti G. Investigação dos métodos avaliativos utilizados por fisioterapeutas na especificidade da neurologia funcional. Fisioter Pesqui. 2013;20(1):31-6.

40. Escola Politécnica de Saúde Joaquim Venâncio. Texto de apoio em registros de saúde. Rio de Janeiro: Fiocruz; 999.

41. Wray NP, Ashton CM, Kuykendall DH, Hollingworth JC. Using administrative databases to evaluate the quality of medical care: a conceptual framework. Soc Sci Med. 1995;40(12):1707-15.

42. Conselho Federal de Fisioterapia e Terapia Ocupacional. Resolução no 414/2012. Dispõe sobre a obrigatoriedade do registro em prontuário pelo fisioterapeuta, da guarda e do seu descarte e dá outras providências. D.O.U. nº99, Seção 1, 23/05/2012.

43. Brasil. Ministério da Saúde. Portaria n. 1.820, de 13 de agosto de 2009. Dispõe sobre os direitos e deveres dos usuários da saúde. Diário Oficial da União. 14 ago 2009.
Received in 11/18/2015

Recebido em 18/11/2015

Approved in 11/29/2016

Aprovado em 29/11/2016 